\title{
UDZIAŁ SIE ZBROJNYCH W PROCESIE ODSUWANIA OD WŁADZY BISKUPÓW ALEKSANDRYJSKICH PODCZAS KONTROWERSJI ARIAŃSKIEJ NA WSCHODZIE
}

W historii Kościoła Aleksandryjskiego okres połowy IV wieku upłynął pod znakiem nieustannej walki o obsadę tronu św. Marka toczonej między zwolennikami soboru w Nicei i ich ariańskimi przeciwnikami. Dobór właściwego kandydata do godności biskupa Aleksandrii znajdował się w polu zainteresowania nie tylko kleru i miejscowego laikatu, ale także dworu cesarskiego, który dla przeforsowania preferowanego przez siebie człowieka zmuszony był niejednokrotnie używać siły zbrojnej.

Po raz pierwszy z tego typu działaniem mamy do czynienia w 339 roku. Oto na przełomie 338 i 339 roku w Antiochii, synod biskupów ariańskich pod przewodnictwem Euzebiusza z Nikomedii, dokonał wyboru na biskupa Aleksandrii Grzegorza z Kapadocji, odsuwając od władzy nicejczyka Atanazego. ${ }^{1}$

${ }^{1}$ Antiochia była miejscem, gdzie w krótkim czasie, to jest na przestrzeni lat 338-341, odbyło się kilka synodów. Nie są one jednak dobrze udokumentowane, przeto wśród badaczy nie ma zgodności również co do daty tego, który pozbawił Atanazego biskupiej godności. Według R.P.C Hansona (The Search for the Christian Doctrine of God. The Arian Controversy 318-381, Edinburgh 1988, s. 268) miało to miejsce zimą 338/339 roku. Rok 339 podaje H. Nordberg (Athanasius and the Emperor, Helsinki 1963, s. 36), J. Gliściński (Wspótistotny Ojcu, Łódź 1992 , s. 417) wskazuje na rok 338, zaś G. Downey (A History of Antioch in Syria from Seleucus to the Arab Conquest, Princeton - New Jersey 1961, s. 358-359) twierdzi, że proces odsuwania Atanazego od władzy biskupiej trwał na synodach antiocheńskich w latach 338 i 340. Wobec Atanazego postawiono zarzuty niekanoniczności elekcji, a także bezprawnego, bo bez uzyskania zgody synodu biskupiego, powrotu na katedrę z wygnania, na które skazał go w 335 r. Konstantyn Wielki. Grzegorz z Kapadocji nie był jedynym typowanym przez arian kandydatem do godności biskupa aleksandryjskiego. Zignorowano osobę niejakiego Pistusa, już wcześniej (w 335 r.) wyznaczanego na następcę Atanazego (G. Bardy, Alexandrie, Antioche, Constantinople (325-451), w: L'Église et les Églises de neuf siècles de douloureuse séparation entre l'Orient et l'Occident. Études et travaux sur l'unité chrétienne offerts à Dom Lambert Beauduin, Chevetogne 1954, s. 186; R. Klein, Constantius II und die christliche Kirche, Darmstadt 1977, s. 69-70, przyp. 142, 144; Hanson, op cit., s. 263, przyp. 98). W opinii J.T. Lienharda (The Arian Controversy: Some Cathegories Reconsidered, ThS 48:1987, s. 417) jego osoba była brana poważnie pod uwagę już w 340 roku; proponowano ten urząd również Euzebiuszowi z Emezy, ten jednak odmówił przyjęcia tego biskupstwa (Hanson, op. cit., s. 268). Wówczas dopiero podjęto decyzję o powołaniu Grzegorza. 
Ta bezprecedensowa elekcja, dokonana została w sposób niekanoniczny, bowiem poza siedzibą Kościoła Aleksandryjskiego, bez zgody lokalnych duchownych i bez aprobaty tamtejszych wiernych. ${ }^{2}$ Mimo to nowy biskup miał za sobą poparcie nie tylko ariańskich współwyznawców, ale także władz państwowych w osobie samego cesarza Konstancjusza II. ${ }^{3}$ Aby jednak Grzegorz mógł przejąć swoje obowiązki, należało przede wszystkim usunąć z Aleksandrii jego poprzednika. Dla Atanazego oznaczało to już drugie w karierze biskupiej wygnanie. ${ }^{4}$ Teraz jednak sytuacja wydawała się być bardziej skomplikowana dla władz państwowych niż za panowania Konstantyna Wielkiego, który w 335 r. skazał Atanazego na pobyt w Galii. Złożyło się na to kilka czynników. Kiedy ojciec Konstancjusza podejmował decyzję o banicji Atanazego, biskup znajdował się w Nikomedii, a więc poza swoją siedzibą, z dala od bezgranicznie oddanych mu wiernych. Teraz przebywał w Aleksandrii, gdzie w każdym momencie mógł liczyć na swych współwyznawców. ${ }^{5}$ Oznaczało to konieczność

${ }^{2}$ Na temat formalnego składu elektoratu w patriarchacie aleksandryjskim por.: E. Przekop, Wschodnie patriarchaty starożytne (IV-X w.), Warszawa 1984, s. 105 i s. 200 przyp. 4; E. Wipszycka, Patriarcha aleksandryjski i jego biskupi (IV-VII w.), „Przegląd Historyczny” 73(1982) s. 177. Sam Atanazy określał powołanie Grzegorza na biskupa jako dokonane niekościelnymi metodami, por. Historia arianorum $(=\mathrm{HA}) 14$.

${ }^{3}$ Filostorgiusz, (HE III 3) wręcz stwierdza, iż to Konstancjusz nakazał wygnać Atanazego i powolać Grzegorza. Potwierdza poparcie Konstancjusza dla Grzegorza także sam Atanazy (Ath., HA 17) nazywając swego oponenta zaufanym człowiekiem władz (ibidem, 14).

${ }^{4}$ Na temat okoliczności, które doprowadziły do pierwszej banicji Atanazego i jego powrocie na katedrę z inicjatywy Konstantyna II piszą: L. Duchesne, Istorija drevnej cerkvii, II, Moskva 1914, s. 118-122, 132; Nordberg, op. cit. s. 27-31, 33; W.H.C. Frend, Athanasius as an Egyptian Christian Leader in the Fourth Century, w: idem, Religion Popular and Unpopular in the Early Christian Centuries, London 1976, s. XVI, s. 23-25, 33; T.D. Barnes, Emperor and Bishops, A.D. 324-344: Some Problems, ,American Journal of Ancient History” 3(1978) 62-65; idem., Constantine and Eusebius, London 1981, s. 235-240, 263; H. Drake, Athanasius' first Exile, „Greek, Roman and Byzantine Studies" 27(1986) 193-202; Hanson, op. cit., s. 259-263. Generalnie przyjmuje się, iż na swym pierwszym wygnaniu przebywał Atanazy między 335 a 337 rokiem. Są w tym względzie jednak różnice poglądów np.: L.W. Barnard (Church-State Relations AD 313-337, „Journal of Church and State" 24:1982, s. 353) podaje jako możliwy pobyt Atanazego na wygnaniu aż do 338 roku.

${ }^{5}$ Do stronników Atanazego należeli nie tylko wyświęcani przezeń duchowni, ale także, i to przede wszystkim, miejscowy laikat, szczególnie z najuboższych kręgów, pozostający w ekonomicznej zależności od Kościoła i korzystający z jego akcji charytatywnych. Potężnym wsparciem dla biskupa były kobiety, zarówno te wyświęcone - diakonisy, jak i pozostające w dobrowolnym bezżeństwie - dziewice, czy wreszcie bezgranicznie oddane sprawom wiary wdowy. Nie należy także zapominać o mnichach z klasztorów pachomiańskich, którzy będą pomocni Atanazemu w staraniach o utrzymanie się na biskupstwie. Właśnie te kręgi zwolenników Atanazego padną później ofiarą prześladowań ze strony jego przeciwników. Szerzej na temat wzajemnych relacji między biskupami a gminą w okresie wczesnego Bizancjum por.: W. Ceran, Kościót wobec antychrześcijańskiej polityki cesarza Juliana Apostaty, Łódź 1981, s. 4-34. O sztabie ludzi podlegających biskupom pisze także E. Wipszycka, Kościót w świecie późnego antyku, Warszawa 1994, 31-37. Na temat powiązań Atanazego z mnichami por.: D.J. Chitty, The Desert a City. An Introduction to the 
liczenia się z poważnymi zamieszkami w mieście, a co za tym idzie, ewentualnością użycia siły zbrojnej dla zdławienia opozycji. Wszelkie zaś rozruchy w Aleksandrii utrudnić mogły, i to w sposób poważny, wywóz zboża egipskiego, od którego dostaw uzależniony był Konstantynopol. ${ }^{6}$ Należy pamiętać również o tym, że Konstantyn Wielki odsuwając Atanazego nie dopuścił jednak do przejęcia biskupstwa przez jego przeciwników, pozostawiając katedrę nieobsadzoną. ${ }^{7} \mathrm{~W}$ tym momencie zaś dokonano wyboru nowego zwierzchnika Kościoła Aleksandryjskiego. Sprzeciw gminy wobec Grzegorza zapowiadał się silny nie tylko z uwagi na jego niezgodny z kanonami wybór, ale również dlatego, iz był on Aleksandryjczykom obcy, gdyż wywodził się z Kapadocji. ${ }^{8}$

Ingres Grzegorza poprzedziło przysłanie do Aleksandrii nowego praefectus Aegypti, niejakiego Filagriusza, podobnie jak Grzegorz - Kapadocczyka ${ }^{9}$. W opinii Grzegorza z Nazjanzu ${ }^{10}$, cieszył się on wśród mieszkańców znacznym poważaniem. Fakt przejęcia przezeń tej godności po raz drugi w tak krytycznym momencie, sugeruje, iż Konstancjusz liczył być może na to, że uda się Filagriuszowi przynajmniej w jakimś stopniu uspokoić wrzenie w mieście, spowodowane ingresem nowego biskupa. Wraz z Filagriuszem przybył do Aleksandrii także cesarski eunuch Arsacjusz. ${ }^{11}$ Dnia 22 marca 339 r. w mieście zjawił się Grzegorz z Kapadocji. Jak podkreśla Atanazy w Historia ariano-

Study of Egyptian Monasticism under the Christian Empire, London, Oxford 1977, s. 1, 28, 37; C.W. Griggs, Early Egyptian Christianity from its Origins to 451, Leiden - New York - Københaven Köln 1991, s. 138.

${ }^{6}$ Oskarżenie o wstrzymywanie wywozu statkami zboża z Aleksandrii do Konstantynopola było jednym z zarzutów, które przeciwnicy Atanazego wysuwali przeciw niemu już przed pierwszym wygnaniem, por.: Socrates, HE I 35; Athanasius, Apologia contra arianos (=AA) 9, 87; Theophanis Chronographia, AM 5827, ed. C. de Boor, Lipsiae 1887. Problem dystrybucji zboża wrócił także jako powód do oskarżeń Atanazego przed drugim wygnaniem. Tym razem jednak przeciwnicy biskupa twierdzili, że sprzedaje on z zyskiem dla siebie zboże przeznaczone przez Konstantyna Wielkiego na rzecz Kościoła Aleksandryjskiego, por. Sozomenus, HE III 9; Na temat rozdawnictwa zboża w Aleksandrii zob. E. Wipszycka, Aleksandryjscy biskupi i cesarskie rozdawnictwo zboża, „Przegląd Historyczny” 87(1996) 399-408. O donacjach czynionych przez Konstantyna Wielkiego na rzecz Kościoła w północnej Afryce por. W.H.C. Frend, The Rise of Christianity, London 1984, s. 485.

${ }^{7}$ Karą wygnania objęty zostal także Jan Arkaf, lider partii melecjańskiej, opozycyjnej względem Atanazego, która wspólnie z arianami dążyła do pozbawienia go biskupiej władzy: Sozom., HE II 31; Socr., HE I 30. Na temat relacji między Atanazym a melecjanami por.: L.W. Barnard, Athanasius and the Meletian Schism, ,Journal of Egyptian Archeology” 59(1973) 181-189; Frend, op. cit., s. 524-527; Griggs, op. cit., s. 123 sq.

${ }^{8}$ Obcość Grzegorza dla mieszkańców Aleksandrii podkreśla Atanazy por. AA 30.

${ }^{9}$ Por. Ath., HA 9-10, 12, 51; Festal index s.a. 339-340, in: Histoire "Acéphale» et Index Syriaque des Lettres festales d'Athanase d'Alexandrie, éd. A. Martin - M. Albert, Paris 1985. Na temat Filagriusza por.: The Prosopography of the Later Roman Empire (=PLRE), vol I: A.D. 264-395, Cambridge 1971, s. 694.

${ }^{10}$ Por. Gregorius Nazianzenus Oratio 21, 28.

11 Por. Ath., HA 10. Na temat Arsacjusza por. PLRE, s. 110. 
rum $^{12}$ i w Apologia contra arianos, ${ }^{13}$ nowemu biskupowi towarzyszyło militarne wsparcie. Informacje o tym, że Grzegorzowi asystowało wojsko napotykamy także u Sozomena ${ }^{14}$ i Teofanesa ${ }^{15}$. Zasięg represji, którym poddano wiernych Atanazemu ludzi zdaje się sugerować, że siły dane do dyspozycji Grzegorzowi mogły zostać wykorzystane. Atanazy opisuje np. zbrojne najście na aleksandryjski kościół Kwirynusa, podczas którego dopuszczono się gwałtu na wiernych mu ludziach ${ }^{16}$. Pisze też o przetrzymywaniu jego współwyznawców w więzieniach $^{17}$, skazywaniu ich na banicję ${ }^{18}$ i roboty publiczne ${ }^{19}$, stosowaniu kar cielesnych ${ }^{20}$, odbieraniu wspieranym przez niego wdowom i żebrakom jałmużny i niszczeniu naczyń, w których trzymali oliwę i wino. ${ }^{21}$ Znając poparcie, jakie miał Atanazy wśród Aleksandryjczyków, należy sądzić, iż wielu z tych restrykcyjnych działań nie udałoby się przeprowadzić bez użycia sił zbrojnych. W przeciwieństwie do Grzegorza z Nazjanzu, odnoszącego się z szacunkiem do Filagriusza, Atanazy uznaje prefekta, w którego gestii znajdowały się przecież lokalne oddziały wojska, za w pełni odpowiedzialnego za prowadzone działania. Pisze, że dlatego po raz wtóry został Filagriusz powołany na urząd prefekta, ponieważ arianie uznali go za zdolnego do przeprowadzenia akcji prześladowań ich przeciwników. ${ }^{22}$ Wymienia ponadto komesa Walacjusza jako poplecznika Grzegorza z Kapadocji w utrwalaniu władzy biskupiej nad gminą $^{23}$. Atanazy informuje również, że zarówno w rejestrze dowódcy sił zbrojnych jak i prefekta Egiptu, znalazły się dokumenty skierowane przeciw

12 Por. Ath., HA 10, 14

13 Por. Idem, AA 30.

14 Por. Sozom., HE III 6. W tym fragmencie tekstu autor miesza jednak ze sobą wydarzenia, które rozegrały się w Aleksandrii w 339 i 356 roku.

15 Theophanes, AM 5833.

${ }^{16}$ Por. Ath., HA 10. Atanazy podaje, że kośçiół zaatakowali pasterze uzbrojeni w miecze i pałki. Użycie mieczy do zwalczania ludzi Atanazego wydaje się jednak wskazywać, że w akcji brali udział także zołnierze. Podczas staré wielu wiernych stratowano, innych pobito i uwięziono, albo wygnano. Przemocy użyto nawet wobec kobiet, ciągnąc je za włosy i odbierając prosforę.

17 Ibidem; idem, AA 30, 33.

${ }^{18}$ Do duchownych, których poddano banicji należał m.in. biskup Sarapammon (Ath., HA 12). Na temat stosowania tego rodzaju kary por. także Ath., AA 33; idem, HA 10.

19 Ath., AA 33 podaje, że na roboty publiczne wysyłano nawet starych biskupów, którzy byli stronnikami Atanazego.

${ }^{20}$ Chłoście poddany został m.in. biskup Potammon, którego bito do tego stopnia, iż zemdlał podczas wymierzania kary i wydawał się być bliski śmierci (Ath., HA 12). Wydaje się, że tego typu karę stosowano powszechnie wobec mnichów i dziewic, starając się zmusić ich do łączności z Grzegorzem (loc. cit.).

21 Idem, HA 13.

22 Por. Ath., HA 9. O akcjach Filagriusza wobec przeciwników arian, prowadzonych również w okresie późniejszym - ibidem, 18.

${ }^{23}$ Por. Ath., HA 12. O ich wzajemnych relacjach zob. także ibidem, 14. Na temat Walacjusza zob. PLRE, s. 929. 
niemu i jego zwolennikom ${ }^{24}$. Samemu Atanazemu udało się uniknąć represji, bowiem w porę opuścił Aleksandrię i wyjechał do Rzymu ${ }^{25}$.

Rok 339 otworzył etap drugiego już wygnania Atanazego, trwającego aż do 346 roku. W tym czasie Kościól zachodni, reprezentowany przez ówczesnego papieża Juliusza, popierany przez Konstansa, brata Konstancjusza, a jednocześnie jego współrządcę rezydującego na Zachodzie, czynił starania o oddanie duchownym nicejskim ich siedzib biskupich ${ }^{26}$. Konstancjusz naciskany przez brata $^{27}$, w obliczu kryzysu, jakie stwarzało zagrożenie perskie we wschodniej części imperium ${ }^{28}$, wyraził zgodę na powrót Atanazego do Aleksandrii. Stało się to już po śmierci Grzegorza. ${ }^{29}$ Niemniej jednak zelżenie ucisku wobec stronników Atanazego w Egipcie nastąpiło już wcześniej, bowiem w 344 roku. ${ }^{30}$ Konstancjusz wydał decyzję o zaprzestaniu działań skierowanych przeciw zwolennikom wygnanego biskupa ${ }^{31}$ i wyznaczył nowego praefectus Aegypti Nestoriusza $^{32}$. Władca trzykrotnie, w osobistych pismach nakłaniał Atanazego do powrotu do Aleksandrii. ${ }^{33}$ Nakazał też Nestoriuszowi anulowanie wszelkich

${ }^{24}$ Rozkazy te odwołał Konstancjusz w związku z powrotem Atanazego z drugiego wygnania, por. Ath., AA 56; idem, HA 22; Sozom., HE III 21; Socr., HE II 23.

${ }_{25}$ Wśród historyków istnieją rozbieżne opinie, co do daty wygnania Atanazego z Aleksandrii. I tak np. G. Bardy (Alexandrie..., s. 186) podaje dzień 18 marca 339. W opinii Barnesa, (Constantine..., s. 264) Atanazy, mimo iż tego dnia został zmuszony do opuszczenia siedziby biskupiej, to jednak wyjechał z Egiptu dopiero tydzień później. Na temat Rzymu jako celu podróży biskupa por.: Ath., HA 11; Theophanes, AM 5838; Sozom., HE III 6, 8; Socr., HE II 11. Los Atanazego podzielił w tym czasie także inny lider partii nicejskiej zwalczanej przez arian, Paweł z Konstantynopola (szerzej o jego karierze piszą: W. Telfer, Paul of Constantinople, ,The Harvard Theological Review" 43(1950) 31-92; M. Simonetti, La crisi ariana nel IV secolo, Roma 1975, s. 159 sq; Hanson, op. cit., s. 280-284; T.D. Barnes, Athanasius and Constantius. Theology and Politics in the Constantinian Empire, London 1993, spec. Appendix 8, s. 212-217).

${ }^{26} \mathrm{Na}$ temat burzliwych negocjacji prowadzonych w sprawie Atanazego, które doprowadziły do jego powrotu na katedrę piszą: Duchesne, op. cit., s. 145-157; Nordberg, op. cit., s. 37- 42; W. Tietze, Lucifer von Caralis und die Kirchenpolitik des Constantius II. Zum Konflikt zwischen dem Kaiser Constantius II und der nikänisch-orthodoxen Opposition (Lucifer von Caralis, Athanasius, Hilarius von Poitiers, Ossius von Cordoba, Liberius von Rom und Eusebius von Vercelli), Stuttgart 1976, s. 224-225; Klein, op. cit., s. 46-51; Chitty, op. cit., s. 269-308; Frend, The Rise..., s. 529-532; Griggs, op. cit., s. 143-144.

27 Stosunki między Konstancjuszem, zwolennikiem poglądów ariańskich, a jego bratem Konstansem, stronnikiem nicejczyków, były bez wątpienia napięte. Wydaje się jednak przesadzone stwierdzenie, przytaczane przez historyków Kościoła, jakoby Konstans zagrozić miał bratu wojną, jeśli ten nie przywróci Atanazemu i Pawłowi tronów biskupich (Socr., HE II 22; Philost., HE III 12; Theophanes, AM 5849).

${ }^{28}$ Por. Downey, op. cit., s. 355-361; A.H.M. Jones, The Later Roman Empire 284-602. A Social, Economic and Administrative Survey, vol. I, Oxford 1986, s. 112.

${ }^{29}$ Grzegorz utrzymał się na katedrze aleksandryjskiej aż do śmierci, to jest do 25 maja 345 roku (Socr., HE II 14 błędnie podaje, iz został z biskupstwa usunięty. Informację tę powtarza Theophanes, AM 5849; Cf. Philost., HE III 12). Atanazy drogą przez Syrię, Palestynę dotarł do Egiptu i 21 października 346 roku przybył do Aleksandrii.

${ }^{30}$ Por. Nordberg, op. cit., s. 41. 
podjętych wcześniej rozkazów skierowanych przeciw biskupowi ${ }^{34}$. Wystosował ponadto pismo do Kościoła w Aleksandrii, nakazujące powtórne przyjęcie Atanazego i grożące karami tym, którzy w związku z jego powrotem wszczynać będą burdy. ${ }^{35}$

Ten wymuszony stan aprobaty Konstancjusza wobec Atanazego ${ }^{36}$ trwał do roku 350. Wówczas to w Galii zamordowany został w wyniku spisku pałacowego Konstans, ${ }^{37}$ dobroczyńca i protektor Atanazego. Śmierć Konstansa uaktywniła stronnictwo ariańskie, dążące do pozbawienia Atanazego biskupstwa. ${ }^{38}$ Konstancjusz jednak nie podjął zdecydowanych działań wobec Atanazego, bowiem borykał się w tym czasie z uzurpacjami Wetraniona i Nepocjana. ${ }^{39}$ Co więcej, wydał nawet odpowiednie instrukcje Nestoriuszowi, aby nie nękał biskupa. ${ }^{40}$

Dopiero w roku 353, kiedy walki z uzurpatorem Magnencjuszem dobiegać będą końca, Konstancjusz wznowił akcję mającą na celu rozprawę z Atanazym. Władca wysłał do Aleksandrii palatii silentiarius Montanusa, ${ }^{41}$ który przybywając w maju 353 r. do Aleksandrii, powołał się na rzekomą pisemną prośbę, skierowaną przez Atanazego do cesarza, a dotyczącą umożliwienia biskupowi przybycia do pałacu cesarza w Mediolanie. Poinformował przy tym metropolitę, że Konstancjusz przychyla się do niej. Biskup wietrząc podstęp nie tylko odmówił wyjazdu, ale co więcej, określił list, na który powoływał się Montanus,

31 Atanazy podaje, że zezwolono na powrót prezbiterom i diakonom wygnanym uprzednio do Armenii (Ath., HA 21), a ponadto zwolniono jego duchownych od ciężarów publicznych i zapewniono im bezpieczeństwo (Ath., AA 54).

32 Por. PLRE, s. 625-626.

33 Por. Ath., AA 52; idem, HA 21; cf. Sozom., HE III 20; Socr., HE II 23.

34 Por. Ath., HA 23; idem, AA 56; cf. Socr., HE II 23. W podobnym tonie otrzymali pisma również prefekci Augustamniki, Libii i Tebaidy (Ath., AA 56; cf. Socr., loc. cit.).

35 Por. Socr., HE III 23; cf. Ath., AA 55; Sozom., HE III 21.

${ }^{36} \mathrm{O}$ udawanej życzliwości Konstancjusza wobec Atanazego za życia Konstansa pisze Sozomen, HE IV 8.

37 Organizatorami zamachu na Konstansa byli Marcellinus, comes rei privatae i Magnencjusz, oficer germański, proklamowany zamiast Konstansa augustem. Szerzej na temat tej uzurpacji por. S. Elbern, Usurpationen im spätrömischen Reich, Bonn 1984, s. 19-21; 39-44. Na temat Marcellinusa, por. PLRE, s. 546; o Magnencjuszu por. PLRE, s. 532.

${ }^{38}$ Por. Socr., HE II 26.

${ }^{39}$ Por. Jones, op. cit., s.113. O Wetranionie por. PLRE, s. 954; na temat Nepocjana por. PLRE, s. 624. Wetranion zrezygnuje z działań przeciw Konstancjuszowi (M.J. Leszka, Uzurpacje $w$ cesarstwie bizantyńskim $w$ okresie od IV do połowy IX w. Łódź 1999, s. 67-68). Nepocjan natomiast zostanie zgładzony przez Magnencjusza.

${ }^{40}$ Por. Ath., HA 51. Konstancjusz obawiał się, i to nie bezpodstawnie, wszelkiego typu kontaktów między Atanazym i Magnencjuszem (biskup będzie musiał później stawić czoło zarzutom jakoby nawiązał współpracę z uzurpatorem, por. Athanasius, Apologia ad Constantium imperatorem (=AC) 6-9. Oznaczałoby to ponowne skierowanie wojsk do Aleksandrii.

${ }^{41}$ Na temat Montanusa por. PLRE, s. 608. Datę 353 podajemy za Nordbergiem, op. cit., s. 64. Według PLRE (loc. cit.) podróż mogła mieć miejsce w 353 lub 354 roku. 
jako fałszerstwo. Stwierdził też, że nie może podporządkować się niewiarygodnemu rozkazowi, aby nie narazić się na gniew monarchy swym nieuzasadnionym pojawieniem się na dworze. ${ }^{42}$ Tak więc próba wywabienia Atanazego z obszaru, gdzie mógł liczyć na pomoc współwyznawców, spełzła na niczym.

Jesienią 353 roku w Arles, podczas obchodów tricennaliów Konstancjusza, w tym czasie niekwestionowanego już pana imperium, ${ }^{43}$ odbył się zainicjowany przez władcę synod, który ponownie pozbawił Atanazego katedry biskupiej44. Decyzje, które wówczas zapadły, nie zostały jednak wyegzekwowane w praktyce. Konstancjusz nadal nie mógł sobie pozwolić na siłowe usunięcie biskupa z Aleksandrii, bowiem wymagałoby to rozproszenia jednostek wojskowych niezbędnych w tym czasie do wojny $z$ Alamanami. ${ }^{45}$

W dwa lata później kolejny wyrok potępiający Atanazego wydany został na synodzie w Mediolanie w 355 roku, którego obradom przysłuchiwał się sam cesarz. $^{46}$ Wówczas Konstancjusz ponownie wysłał swego człowieka, notariusza Diogenesa, ${ }^{47}$ do Aleksandrii. Ten od września do grudnia 355 roku, unikając osobistego kontaktu z Atanazym, ${ }^{48}$ usiłował zmontować przeciw niemu koalicję i doprowadzić do usunięcia biskupa z miasta. Jednakże bezskutecznie. ${ }^{49}$ Dla władz jasnym się stało, iż rozwiązanie kwestii pozbawienia Atanazego jurysdykcji nad Kościołem Aleksandryjskim bez użycia sił wojskowych, jest niemożliwe.

W styczniu 356 roku do Aleksandrii przybył dux Syrianus. ${ }^{50}$ Wydarzeniu temu towarzyszyła gwałtowna koncentracja wojsk ściągniętych z głębi Egiptu i Libii. ${ }^{51}$ Wraz z Syrianusem zjawił się w mieście Hilariusz, cesarski notariusz. ${ }^{52}$ Ich przybycie spowodowało natychmiastowe uaktywnienie się stronnictwa

${ }^{42}$ Na temat pobytu Montanusa w Aleksandrii por.: Ath., AC 19-22; cf. Historia Acephala I 8; Festal Ind., s. a. 353.

${ }^{43}$ Magnencjusz, pokonany przez siły Konstancjusza popełnił samobójstwo w sierpniu 353 roku.

${ }^{44} \mathrm{Na}$ temat synodu w Arles por. K.M. Girardet, Constance II, Athanase et l' edit d' Arles 353. A propos de la politique religieuse de l' empereur Constance II, w: Politique et théologie chez Athanase d' Alexandrie. Actes du colloque de Chantilly 23-25 septembre 1973, Paris 1974, 63-91.

45 Por. Nordberg, op. cit., s. 47.

${ }^{46}$ Por. Hanson, op. cit., s. 332-334; Tietze, op. cit., s. 55-60; Klein, op. cit., s. 35-37; S. Bralewski, Imperatorzy późnego Cesarstwa Rzymskiego wobec zgromadzeń biskupów, Łódź 1997, s. 145.

47 Na temat Diogenesa: por. PLRE, s. 255.

48 Por. Ath., AC 22.

49 Historia Acephala I 9; cf. Festal Ind. sa. 355.

50 Historia Acephala I 10.Na temat Syrianusa por. PLRE s. 872. Istnieją rozbieżności co do ścisłego określenia momentu wkroczenia Syrianusa do miasta. Podawana jest najczęściej data 5 (Nordberg, op. cit., s. 49) lub 6 stycznia (Frend, The Rise, s. 536 ).

${ }^{51}$ Por. Sozom., HE IV 9; cf. A. Demandt, Die Spätantike. Römische Geschichte von Diocletian bis Justinian 284-565 n. Chr., München 1989, s. 89.

52 Historia Acephala I 10. Na temat Hilariusza por. PLRE, s. 434. 
ariańskiego w Aleksandrii. ${ }^{53}$ Atanazy ponownie zażądał od Syrianusa przedstawienia mu pisma cesarskiego z rozkazem opuszczenia katedry. Powołał się przy tym na poprzednie rozporządzenia władcy, w których Konstancjusz zalecał biskupowi pozostanie w świątyniach i nie dawanie posłuchu tym, którzy dążą do destabilizacji i niepokojów. ${ }^{54}$ Wówczas Syrianus, który nie miał takiego polecenia cesarskiego na piśmie, bądź nie chciał go publicznie ujawnić, poprzysiągł w obecności notariusza Hilarego, że nie zakłóci spokoju Kościoła i sprawę skieruje do rozpatrzenia władcy. ${ }^{55}$ Jak się wkrótce okaże, był to jedynie zabieg mający na celu uśpienie czujności Atanazego i wiernych mu ludzi.

Nocą z 7 na 8 lutego 356 roku wojsko dowodzone przez Syrianusa, któremu asystował Hilariusz, uderzyło na aleksandryjski kościół Teonasa, gdzie wierni pod przewodnictwem Atanazego oddawali się modlitwie. ${ }^{56}$ Wydaje się, iż zasadniczym celem akcji miało być przede wszystkim pochwycenie biskupa. $\mathrm{Z}$ lakonicznej wzmianki, przekazanej nam przez Sozomena, ${ }^{57}$ dowiadujemy się, iż miejsce pobytu Atanazego ujawnione zostało władzom w wyniku donosu. Żołnierze uzbrojeni w miecze, łuki i kije otoczyli świątynię, a Syrianus wtargnął do środka starając się aresztować Atanazego. Kiedy wierni zaczęli wychodzić z kościoła, biskup korzystając z ogólnego zamieszania, zdołał zmylić żołnierzy i w otoczeniu wiernych sobie duchownych, niepostrzeżenie wymknął się ze świątyni. ${ }^{58} \mathrm{Z}$ protestu, który wierni Atanazemu ludzie skierowali do cesarza Konstancjusza, a który zamieścił ten biskup w Historia arianorum, dowiadujemy się, ze podczas akcji Syrianusa nie obeszło się bez rozlewu krwi, gdyż wódz nakazał żołnierzom strzelać do zebranych. Wśród zabitych miały znaleźć się m.in. dziewice. Ludzie byli tratowani i ranieni strzałami. Żołnierze biorący udział w akcji splądrowali świątynię i dopuścili się czynów niegodnych wobec kobiet ${ }^{59}$. Jeśli przeanalizujemy dokładniej relacje dotyczące wydarzeń, które rozegrały się w kościele Teonasa, to bez wątpienia musimy stwierdzić, że w świątyni doszło do szarpaniny i ogólnego zamieszania, wśród którego ludzie zostali zapewne poturbowani. Trudno jednak ustalić z całą

53 Por. Ath., AC 22.

54 Por. Ath., AC 22-25. Cf. idem, HA 50.

55 Por. Ath., AC 24.

56 Por. Ath., AC 25; idem, HA 81; idem, Apologia de fuga sua (=AF) 24; Festal Index s.a. 356; Historia Acephala I 10; Theodoretus, HE II 13 (błędnie podaje wodza Sebastiana jako prowadzącego akcję); cf. C. Haas, The Alexandrian Riots of 356 and George of Cappadocia, ,Greek, Roman and Byzantine Studies" 32(1991) s. 282.

57 Por. Sozom., HE IV 8.

58 Ucieczka ta rozpoczyna kolejne, tym razem sześcioletnie, wygnanie Atanazego. Biskup, mimo iż pozbawiony możliwości bezpośredniego kierowania gminą, nadal pozostawał w jej pobliżu, znajdując schronienie wśród wiernych sobie mnichów pachomiańskich, por. Chitty, op. cit. s. 37 .

${ }^{59}$ Por. Ath., HA 81. 
pewnością, czy wśród wiernych były ofiary śmiertelne. Poza przekazem Atanazego żadne inne źródła nie wspominają o tym.

W cztery miesiące po ucieczce Atanazego, do Aleksandrii przybył kolejny wysłannik cesarza Konstancjusza, comes Herakliusz, ${ }^{60}$ w towarzystwie nowego praefectus Aegypti Katafroniusza. ${ }^{61}$ Ich przyjazd nie pozostawił Aleksandryjczykom wątpliwości co do prawdziwych zamiarów władcy wobec Atanazego i jego ludzi. Zostali oni uznani za wrogów cesarza i mieli być poddani represjom. ${ }^{62} \mathrm{~W}$ połowie czerwca 356 roku Herakliusz oraz Katafroniusz wspólnie $\mathrm{z}$ rationalis Aegypti Faustinusem i heretykiem Bithynusem, wziąwszy do pomocy młodych ludzi wierzących w idole, uderzyli na Wielki Kościół (prawdopodobnie chodzi o kościół Teonasa), gdzie nadal gromadzili się wierni Atanazemu ludzie: poturbowano kobiety, sprofanowano świątynię i spalono sprzęty kościelne. Na podstawie zachowanej relacji nie możemy jednak stwierdzić, czy w akcji tej uczestniczyli żołnierze; wydaje się, że tym razem nie. W innym miejscu jednak, Atanazy nie pozostawia nam wątpliwości co do tego, że w czerwcu 356 roku wojsko brało udział w prześladowaniu jego zwolenników. W Historia arianorum Atanazy informuje, że gdy jego przeciwnicy przeszukiwali domy, ogrody, a nawet grobowce, plądrując je i niszcząc pod pozorem, że szukają zbiegłego biskupa, asystowało im wojsko. Co więcej, żołnierze otrzymali część mienia zagrabionego zwolennikom Atanazego. ${ }^{63}$

Na nowego biskupa wyznaczony został przez arian niejaki Jerzy z Kapadocji, człowiek o gwałtownym charakterze i niejasnej przeszłości ${ }^{64}$; miał on jednak pełne poparcie cesarza Konstancjusza. W piśmie skierowanym do mieszkańców Aleksandrii władca określił Jerzego jako doskonale obeznanego w sprawach wiary i zdolnego do przewodzenia tamtejszemu Kościołowi. ${ }^{65}$

Jerzy przybył jednak do Aleksandrii dopiero w lutym 357 roku. $^{66}$ Jego wkroczeniu do miasta towarzyszyła militarna eskorta. ${ }^{67}$ Nowy biskup od samego początku dał się poznać jako człowiek nie stroniący od stosowania przemocy

${ }^{60} \mathrm{Na}$ temat Herakliusza por. PLRE s. 418.

${ }^{61}$ Na temat Katafroniusza por. PLRE, s. 186. O przybyciu obu dostojników do Aleksandrii relacjonują: Ath., HA 54; Historia Acephala II 1.

${ }^{62}$ Por. Ath., HA 55-57.

${ }^{63}$ Ibidem 58.

${ }^{64}$ Wyniesienie Jerzego miało miejsce na synodzie antiocheńskim w 351 lub 352 roku (Hanson, op. cit., s. 325; cf. Girardet, op. cit., s. 67). Nowy zwierzchnik Kościoła Aleksandryjskiego rozpoczynał karierę jako dostawca mięsa dla wojska, przy czym, jak podaje Grzegorz z Nazjanzu (Oratio 21, 16), dopuścić miał się malwersacji (cf. Ath., HA 51,75). Atanazy określał Jerzego jako Kapadocczyka (Ath., HA 75; idem, AC 6). Zdaniem Ammiana Marcellina biskup wywodził się z Cylicji ( Ammianus Marcellinus, Rerum gestarum XXII 11, 4 with an English Translation by J.C. Rolfe, vol. II, London 1956, s. 259).

${ }^{65}$ Por. Ath., AC 30.

${ }^{66}$ Por. Historia Acephala, II, 2.

${ }^{67}$ Por. Ath., HA 75: Festal Index 19. 
i wykorzystywania wojska do dławienia opozycji i trzymania kontroli nad Kościołem Aleksandryjskim. Represjom poddani zostali stronnicy Atanazego, zarówno spośród kleru jak i wiernych świeckich. ${ }^{68}$ Szczególnej pomocy w tym względzie udzielił Jerzemu dux Aegypti manichejczyk Sebastian. ${ }^{69}$ On to w maju 357 roku z oddziałem wojska uderzył na grupę modlących się w pobliżu cmentarza osób, które pomimo odejścia Atanazego nadal pozostawały mu wierne i nie chciały uznać jego następcy. Drogą zastraszania starał się zmusić dziewice do przyjęcia wiary ariańskiej, a jeśli odmawiały, nakazał żołnierzom, by bili je po twarzach. ${ }^{70}$ Represjom poddał również czterdziestu mężczyzn, poleciwszy wychłostać ich palmowymi rózgami. Kara ta do tego stopnia okazała się dotkliwa, że niektórzy z nich zmarli, inni zaś musieli się leczyć. ${ }^{71}$ Pochwyconych mężczyzn i dziewice skazywano na wygnanie do Wielkiej Oazy. ${ }^{72}$ Wojsko brało również udział w akcji aresztowań biskupów. ${ }^{73} \mathrm{Na}$ mocy rozporządzenia Sebastiana, wydanego zarządcom i dowódcom wojskowym, prześladowano prawowiernych duchownych, a zastępowano ich arianami. ${ }^{74}$ Prezbiterów i mnichów karano chłostą i przypiekano żelazem, ${ }^{75}$ żołnierze zaś wyrzucali z domów krewnych tych duchownych, których represjonowano ${ }^{76}$. Sebastian bowiem był odpowiedzialny za wprowadzenie w życie rozkazów Konstancjusza dotyczących przekazania kościołów w Egipcie i Libii arianom. ${ }^{77}$ Kiedy zaś w 358 roku Jerzy zmuszony był opuścić Aleksandrię, szukając schronienia w Konstantynopolu przed rozjuszoną jego akcją prześladowań gminą, ${ }^{78}$ to Sebastian, przy pomocy wojska, odzyskał kontrolę nad kościołami, które przejęli zwolennicy Atanazego i ponownie przekazał je arianom. ${ }^{79}$

${ }^{68}$ Por. Socr., HE II 26; Sozom., HE IV 10; Ath., AF 6.

69 Por. PLRE, s. 812-813.

70 Por. Ath., AF 6; idem AC 27; cf. idem, HA 72; Socr., HE II 28; Theodoretus, HE II 14.

71 Por. Ath., AF 7; Socr., loc. cit.; Theodoretus, loc. cit.

72 Por. Ath., AF 7; idem, HA 72; Theodoretus, loc. cit.

73 Por. Socr., HE II 28; Theodoretus, loc. cit.

${ }^{74}$ Atanazy (HA 72) podaje listę biskupów, którzy zostali zesłani i miejsca ich banicji, takie jak np.: Górna Oaza, Ammoniaka, czy okolice Klysmy. Nadmienia, że niektórych z wygnanych duchownych zmuszono do pracy w kamieniołomach. W innym miejscu opisuje losy subdiakona Eutychiusza skazanego, jak pospolitego przestępcę, na pobyt w kopalniach w Fano (HA 60).

75 Por. Ath., HA 70, 72 .

${ }^{76}$ Por. Ath., HA 63. W akcji tej uczestniczył Gorgoniusz, zwierzchnik lokalnej policji.

77 Por. Ath., HA 70.

78 Jerzy opuścił Aleksandrię w październiku 358 roku po tym jak omal nie zostal zlinczowany przez thum w kościele Dionizego w sierpniu tegoż roku (Historia Acephala II 3). Ten bezprecedensowy wybuch fali nienawiści wobec biskupa był możliwy z uwagi na nieobecność w Aleksandrii chroniącego go naczelnego dowódcy sił wojskowych Egiptu. Jerzy kierował Kościołem Aleksandryjskim przebywając w Konstantynopolu. Powrócił do Aleksandrii dopiero w listopadzie 361 roku.

${ }^{79}$ Por. Historia Acephala II 4; Sozom., HE IV 10. Po tych wydarzeniach Konstancjusz wysłał do Aleksandrii notariusza Paulusa z nakazem podjęcia akcji represyjnych wobec ludzi Atanazego. (Historia Acephala II 5; Sozom., HE IV 10. Na temat Paulusa por. PLRE, s. 683-684). 
W roku zaś 360, pod nieobecność Jerzego, inny z dowódców wojskowych, dux Aegypti Artemiusz, ${ }^{80}$ prowadził poszukiwania Atanazego pośród mnichów w Tebaidzie ${ }^{81}$. On również, wspólnie z Faustinusem, ówczesnym praefectus Aegypti, torturował pewną dziewicę o imieniu Eudajmonis, starając się wymusić na niej informację o miejscu ukrycia zbiegłego biskupa. ${ }^{82}$

Sozomen informuje, że Jerzego obawiali się nie tylko stronnicy Atanazego, ale także poganie. Wprowadził on bowiem do miasta zbrojne oddziały pod komendą naczelnego dowódcy garnizonów Egiptu, aby podjąć działania zmierzające do zagrabienia pogańskiego mienia świątynnego i likwidacji ich kultu. ${ }^{83}$ Artemiusz dokonał wówczas najścia na świątynię Serapisa i ograbił ją z wotów i drogocennych sprzętów. ${ }^{84}$ Wywołało to falę rozruchów wznieconych przez pogan, oburzonych sprofanowaniem świątyni, które zostały przez Artemiusza krwawo stłumione.

Rządy Jerzego z Kapadocji zakończyły się w grudniu 361 roku, w zaledwie miesiąc po jego powrocie z Konstantynopola. Na wieść o zgonie cesarza Konstancjusza, protektora Jerzego, tłumiona przez Aleksandryjczyków nienawiść wobec narzuconego biskupa znalazła swe ujście. Został on aresztowany i osadzony w więzieniu; wkrótce później rozjuszony tłum wdarł się do budynku dokonując na nim samosądu ${ }^{85}$.

Śmierć Konstancjusza i Jerzego z Kapadocji umożliwiły Atanazemu powrót na biskupstwo: nastąpiło to w lutym 362 roku. ${ }^{86}$ Powrót ten jednak nie okazał się trwały. Wkrótce bowiem cesarz Julian, zwolennik powrotu do wiary pogańskiej, zaniepokojony prowadzoną przez Atanazego działalnością chrystianizacyjną nakazał, mu natychmiastowe opuszczenie Aleksandrii. ${ }^{87}$ Polecenie władcy dostarczył biskupowi cesarski wysłannik Pytiodor. ${ }^{88}$ Instrukcje w sprawie postępowania wobec Atanazego otrzymał także praefectus Aegypti Ekdikiusz Olimpus, ${ }^{89}$. Użycie wojsk dla wyegzekwowania polecenia władcy okazało się

${ }^{80}$ Por. PLRE, s. 112.

${ }^{81}$ Por. Chitty, op. cit., s. 37.

82 Por. Festal Index, s.a. 359-361.

${ }^{83}$ Sozom., HE IV 30; cf. Socr., HE III 3. Na temat działań Jerzego skierowanych przeciw poganom zob. Socr., HE III 2; Ammianus Marcellinus, Rerum gestarum XXII 11, 3-8.

${ }^{84}$ Por. Sozom., loc. cit.

${ }^{85} \mathrm{Na}$ temat okoliczności śmierci Jerzego z Kapadocji, która nastąpiła 24 grudnia 361 roku zob. Sozom., HE V 7; Socr., HE III 2; Historia Acephala II, 8-10; cf. Ammianus Marcellinus, Rerum gestarum XXII 11, 8-10.

${ }^{86}$ Atanazy przybył do Aleksandrii w niecałe dwa tygodnie po tym, jak cesarz Julian, następca Konstancjusza, opublikował dokument zezwalający na powrót z wygnania tym biskupom, których usunął jego poprzednik. Na temat pobudek, którymi kierował się władca wydając niniejszy reskrypt por. Nordberg, op. cit., s. 55.

${ }^{87}$ Por. Sozom., HE V 15.

${ }^{88}$ Por. Historia Acephala III 5; PLRE, s. 756.

${ }^{89}$ Por. Ceran, op. cit., s. 171. 
zbędne, ponieważ biskup, tym razem dobrowolnie, 24 października 362 roku udał się na wygnanie. ${ }^{90}$

Prawa Atanazego do zajmowania katedry aleksandryjskiej potwierdził w 363 roku następca Juliana Jowian, ${ }^{91}$ jednak jego panowanie okazało się zbyt krótkie, aby ustabilizować sytuację biskupa. Nowy władca Walens, pozostający pod silnymi wpływami arian, ${ }^{92} \mathrm{w}$ maju 365 roku podjął decyzję o wydaleniu tych biskupów, których przywrócił Julian, a wygnał poprzednio Konstancjusz. ${ }^{93}$ Decyzja ta dotknęła także Atanazego. Rozkaz cesarski wywołał wrzenie w Aleksandrii, w każdej chwili grożące buntem. ${ }^{94}$ Ludność domagała się od prefekta (był nim wówczas Flawianus ${ }^{95}$ ), aby ponownie rozpatrzył polecenie cesarza. Argumentowano to faktem, że co prawda Konstancjusz podjął decyzję o banicji Atanazego, ale on też zezwolił na jego powrót. Julian natomiast, który przywrócił biskupów wygnanych przez Konstancjusza, ponownie usunął Atanazego, który swój powrót na katedrę zawdzięczał dopiero Jowianowi. W związku z oporem ludności, która nie chciała dopuścić do pozbawienia jej duchowego przywódcy, władze zdecydowały się uciec do podstępu. Nocą 5 października 365 roku prefekt wspólnie z dux Aegypti Wiktorynusem ${ }^{96}$, dokonali zbrojnego najścia na kościół Dionizego, gdzie spodziewano się znaleźć biskupa. Nie zastali go jednak. Próba uwięzienia Atanazego przy wykorzystaniu oddziału wojska zakończyła się niepowodzeniem. ${ }^{97}$ Powtórzyła się więc sytuacja z lutego 356 roku, gdzie pomimo zaplanowanej akcji z udziałem żołnierzy udało się Atanazemu zbiec. O ile jednak w pierwszym przypadku można złożyć odpowiedzialność za ucieczkę biskupa na karb ogólnego zamieszania i niedopracowania akcji, o tyle w drugim możemy przypuszczać, że Atanazy miał swoich stronników w kręgach władz miejskich, bądź szeregach wojska, i to właśnie ich informacja pomogła mu uniknąć aresztowania.

Atanazy pozostał na wygnaniu do lutego 366 roku. Wówczas to Walens, obawiając się buntu w Aleksandrii i biorąc pod uwagę wpływy, jakimi cieszył

90 Atanazy znalazł schronienie na terenie Tebaidy (Chitty, op. cit., s. 37). Zarówno u Sokratesa (HE III 14), jak i u Teodoreta (HE III 9) spotykamy błędne informacje, jakoby w czasie tego wygnania Atanazy potajemnie powracal do Aleksandrii. Stało się to możliwe dopiero po śmierci Juliana.

91 Por. Socr., HE III 24; Theodoretus, HE IV 2-3. Władca odrzucił starania arian zmierzające do przekazania katedry aleksandryjskiej Lucjuszowi, ich stronnikowi, wybranemu na następcę Jerzego z Kapadocji (Historia Acephala IV, 7). Atanazy przybył do Aleksandrii 14 lutego 364 roku.

92 Por. J. Češka, Rimsky štát a katolická cirkiev ve IV stoleti, Brno 1983, s. 95-96.

93 Por. Sozom., HE VI 12; Theophanes, AM 5861.

$94 \mathrm{Na}$ temat sytuacji w Aleksandrii i wydarzeniach, które nastąpiły w rezultacie decyzji podjętych przez Walensa por. Sozom., HE VI 12; cf. Historia Acephala V 1-4.

95 Por. Historia Acephala V 2; PLRE, s. 343.

96 Por. PLRE, s. 963.

97 Zarówno Sozomen (HE VI 12), Teofanes (AM 5861) jak i Sokrates (HE IV 13) podają jako jedno z miejsc ukrycia Atanazego grobowiec jego ojca. 
się biskup na terenie Egiptu i Libii, wreszcie mając na uwadze stanowisko własnego brata Walentyniana, zwolennika nicejczyków, zdecydował się przywrócić Atanazego na biskupstwo. ${ }^{98}$ Zapewne do decyzji tej skłoniła władcę także trwająca od 365 do 366 roku uzurpacja Prokopiusza ${ }^{99}$, przy której ewentualne rozruchy w Aleksandrii mogły poważnie skomplikować i tak trudną już sytuację.

$\mathrm{Z}$ użyciem wojska w celu przekazania władzy nowemu biskupowi Egiptu cesarz Walens wstrzymał się aż do zgonu Atanazego. Do 2 maja 373 roku, a więc do śmierci, pozostał on bowiem niekwestionowanym zwierzchnikiem tamtejszego Kościoła. Tuż przed śmiercią, Atanazy obawiając się, że katedra może wpaść ponownie w ręce ariańskie, wyznaczył na swego następcę Piotra, zwolennika Nicei. ${ }^{100}$ Odejście Atanazego natychmiast uaktywniło stronnictwo ariańskie, które, podjęło bezpośrednie starania na dworze cesarskim w Antiochii, aby biskupem aleksandryjskim uczynić Lucjusza. Ich poczynania w tym względzie popierał Euzojusz, zwierzchnik Kościoła Antiocheńskiego, bliski doradca Walensa. ${ }^{101}$ On to razem z Magnusem, comes sacrum largitionum Walensa ${ }^{102}$ udali się do Aleksandrii, aby osobiście dopilnować ingresu arianina. ${ }^{103}$ Sokrates ${ }^{104}$ i Teodoret ${ }^{105}$ wyraźnie stwierdzają, iż przybyli oni do miasta w asyście cesarskich żołnierzy. Starania o usunięcie Piotra podjął także praefectus Aegypti Eliusz Palladiusz, który, jak podaje Teodoret, już na parę dni przed przybyciem Magnusa i Lucjusza, korzystając z pomocy pogan i żydów starał się zmusić Piotra do opuszczenia Kościoła. ${ }^{106}$ Cesarz Walens skierował odpowiednie rozkazy zarówno do Palladiusza, jak i do wojska, aby spieszyło z pomocą. ${ }^{107}$ Zdanie to pozwala stwierdzić, że żołnierze wzięli czynny udział w działaniach zmierzających do przejęcia przez Lucjusza kontroli nad powierzonym mu Kościołem. Ofiarą tej represji padł przede wszystkim Piotr, którego pochwycono i osadzono w więzieniu. Udało mu się jednak zmylić straże i opuścić potajemnie Aleksand-

${ }^{98}$ Por. Sozom., loc. cit.; cf. Theoph., loc. cit; Socr., loc. cit.; 1 lutego 366 r. Brasydes, cesarski notariusz, dostarczył do Aleksandrii pismo Walensa, zezwalające na powrót Atanazego (Historia Acephala V 6-7; Festal Index s.a. 365 (błędna datacja). Na temat Brasydasa por. PLRE, s. 164-165.

${ }^{99}$ Por. PLRE, s. 742-743.

${ }^{100}$ Por. Socr., HE IV 20; Theodoretus, HE IV 20; Rufinus, HE II 3. Obawy Atanazego nie były bezpodstawne. Arianie jeszcze w 367 roku starali się zainstalować w Aleksandrii Lucjusza, swego człowieka, jako konkurencyjnego biskupa Aleksandrii. Poczynania te zakończyły się wówczas fiaskiem (Historia Acephala V 11-13; Griggs, op. cit., s. 180-181). Lucjusz był tym samym prezbiterem, którego starania o aleksandryjską katedrę odrzucił jeszcze cesarz Jowian (patrz przyp. 91).

101 Por. Socr., HE IV 21; cf. Sozom., HE VI 19.

102 Por. PLRE, s. 536.

103 Por. Sozom., HE IV 19; Socr., HE IV 21; Theodoretus, HE IV 21-22.

104 Por. Socr., loc. cit.

105 Por. Theodoretus, HE IV 22.

106 Por. Theodoretus, HE IV 21. Na temat Palladiusza por. PLRE, s. 661.

107 Por. Socr., HE IV 21. 
rię. ${ }^{108}$ Duchownym i dziewicom powiązanym ze zbiegłym biskupem postawiono zarzut udziału w buncie. ${ }^{109}$ Magnus starał się zmusić do zmiany wiary prezbiterów i diakonów przekupstwem lub groźbą. Opornych wygnano do Heliopolis w Fenicji. Jedenastu biskupów egipskich poddano karze zesłania do Diocezarei w Palestynie. Prefekt Palladiusz represjami objął także ludzi świeckich, których bito, torturowano, kierowano do pracy w kopalniach, ${ }^{110}$ ciągnięto przed sądy i więziono. ${ }^{111}$ Zgodnie $\mathrm{z}$ poleceniem cesarza Walensa prefekt miał wygnać wszystkich tych, których wskaże Lucjusz, i to przy pomocy wojska. ${ }^{112}$ Korzystając $z$ pomocy zbrojnych oddziałów ariański biskup uderzył więc na egipskie klasztory, podporę ortodoksji. ${ }^{113}$ Mnichów pozbawiano wolności, odzierano z szat, poddawano chłoście; niektórych ukamienowano, inni zginęli od miecza. Byli też tacy, których skazano na wygnanie. ${ }^{114}$

Lucjusz utrzymał się na katedrze do 378 roku, kiedy to Piotr ponownie przybył do Aleksandrii. Mogło to być rezultatem zmiany polityki cesarza Walensa, który zaangażowany w problemy konfliktu z Gotami zezwolił części wygnanych duchownych nicejskich na powrót. ${ }^{115}$ Społeczność aleksandryjska pozbawiła Lucjusza katedry i zmusiła do szukania schronienia w Konstantynopolu, ${ }^{116}$ oddając tron biskupi ponownie Piotrowi. Jak informuje Sozomen, ${ }^{117}$ cesarz Walens nie był tym razem w stanie podjąć interwencji w sprawie usuniętego Lucjusza z uwagi na zagrożenie stolicy przez Gotów, jego zaś śmierć w bitwie pod Adrianopolem i objęcie władzy przez Teodozjusza przyczyniły się do zmiany w polityce religijnej imperium. Nowy władca opowiedział się bowiem za zwolennikami soboru w Nicei ${ }^{118}$, co uniemożliwiło Lucjuszowi powrót na katedrę, a utwierdziło pozycję Piotra, czyniąc go podporą ortodoksji ${ }^{119}$.

108 Por. Sozom., HE IV 19; Socr., HE IV 21-22; cf. Theodoretus, HE IV 21. Piotr, podobnie jak jego poprzednik Atanazy, znalazł schronienie w Rzymie (Rufinus, HE II 3; Socr., loc. cit; Sozom., HE IV 22).

109 Por. Sozom., HE IV 19.

${ }^{110}$ Por. Theodoretus, HE IV 22.Na temat akcji represyjnych zob. także Socr., HE IV 22.

111 Por. Socr., HE IV 20; Theodoretus, loc. cit.

112 Por. Socr., HE IV 22; cf. Sozom., HE IV 19.

113 Por. Socr., HE IV 24; Sozom., HE VI 20; cf. Rufinus, HE II 3.

114 Por. Socr., loc. cit.; Chitty, op. cit., s. 47.

115 Dyskusję na ten temat zob. R. Snee, Valens' Recall of the Nicene Exiles and Anti- Arian Propaganda, „Greek, Roman and Byzantine Studies” 26(1985) 395-419.

116 Por. Socr., HE IV 37; Sozom., HE VI 39. W opinii Griggsa (op. cit., s. 183) powrót Piotra miał miejsce dopiero po śmierci Walensa. Hanson (op. cit., s. 805) twierdzi, że usunięcie Lucjusza z Aleksandrii nastąpiło już za panowania Teodozjusza.

117 Por. Sozom., HE, loc. cit. Zdanie to wydaje się potwierdzać, iż przybycie Piotra do Aleksandrii miało miejsce jeszcze przed śmiercią władcy.

${ }^{118}$ Na temat polityki religijnej cesarza Teodozjusza Wielkiego zob. W. Ensslin, Die Religionspolitik des Kaisers Theodosius d. Gr., München 1953; N.Q. King, The Emperor Theodosius and the Establishment of Christianity, London 1961; R. Klein, Theodosius der Grosse und die christliche Kirche, „Eos” 82(1994) 85-121. 
Reasumując zebrany przez nas materiał należy podkreślić, że na przestrzeni krótkiego czasu, to jest od 339 do 373 roku, Aleksandria kilkakrotnie była świadkiem użycia sił zbrojnych w celu odsunięcia od władzy aktualnie kierującego Kościołem biskupa i dokonania ingresu jego następcy, aprobowanego przez dwór cesarski. Do egzekwowania poleceń władcy na miejscu wykorzystywano przedstawicieli lokalnej administracji (np. praefectus Aegypti) i dowódców wojsk (np. dux Aegypti). Rozkazy dotyczące sposobów postępowania były przysyłane $\mathrm{z}$ dworu za pośrednictwem cesarskich urzędników, którzy wielokrotnie na miejscu dopilnowywali wyegzekwowania cesarskich poleceń. Wydarzenia $\mathrm{z}$ roku 356, kiedy z Aleksandrii usuwano Atanazego, pokazują, że decyzja o użyciu siły zapadła wówczas, gdy wykorzystano już wszystkie inne możliwości zmuszenia danego biskupa do opuszczenia katedry. Władze liczyły się bowiem z poważnymi zamieszkami w mieście, czego z uwagi na trwające na przykład uzurpacje czy wojny starali się uniknąć. We wszystkich omawianych przez nas przypadkach dwór cesarski zadbał o to, aby nowi biskupi zostali wsparci dodatkowymi siłami wojskowymi, przysłanymi z zewnątrz, a więc spoza samej Aleksandrii. Sugeruje to, że władcy często uznawali lokalne oddziały za niewystarczające do podołania wyznaczonym im zadaniom. Wojsko brało udział w akcjach zmierzających do aresztowania skazanego na wygnanie biskupa, działając zarówno na terenie samej Aleksandrii, jak i poza nią. Jest jednak rzeczą charakterystyczną, że poczynania te z reguły kończyły się niepowodzeniem. Korzystając z pomocy zbrojnych oddziałów nowo ustanowieni zwierzchnicy Kościoła Aleksandryjskiego starali się przemocą podporządkować sobie gminę. Szczególną aktywność w tym względzie wykazali Jerzy z Kapadocji i Lucjusz. Z inspiracji tych ariańskich biskupów dowódcy wojskowi prowadzili akcje skierowane nie tylko przeciw stronnikom Atanazego i Piotra wywodzącym się z kręgu kleru i laikatu, ale i przeciw mnichom z klasztorów pachomiańskich, stanowiących podporę dla ortodoksyjnych biskupów. Dochodziło wówczas do licznych aktów gwałtu i przemocy. Na przykładzie losów Jerzego z Kapadocji możemy powiedzieć, iż jedynie stałej obecności wojska w mieście zawdzięczał on utrzymanie się na katedrze. Gdy go zabrakło, musiał uchodzić z Aleksandrii, w obawie o utratę życia. Mimo kilkakrotnego przekazywania przez cesarzy Kościoła Aleksandryjskiego w ręce arian, wspieranych przez zbrojne oddziały, wpływy ich pronicejskich oponentów pozostawały nadal bardzo silne. Świadczy o tym wielokrotny powrót na katedrę Atanazego, a później jego następcy Piotra. Nawet pozostający pod silnymi wpływami arian cesarz Walens, musiał liczyć się z tym, że w wyjątko-

${ }^{119}$ W akcie Cunctos populos Teodozjusz nakazał wszystkim wyznawać wiarę taką, jaką wyznają Damazy, biskup Rzymu i Piotr, zwierzchnik Kościoła Aleksandryjskiego (Theodosiani libri XVI cum constitutionibus Sirmondianis XVI 1, 2, ed. T. Mommsen - P.M. Meyer, vol. 1-2, Berolini 1954; Sozom., HE VII 4; Philost., HE IX 19). 
wych okolicznościach, dla zabezpieczenia ładu i spokoju w Aleksandrii, będzie musiał zgodzić się na obecność w mieście ortodoksyjnego biskupa, mimo że wcześniej wydał wojsku rozkaz jego usunięcia.

\section{THE PARTICIPATION OF THE ARMED FORCES IN THE PROCESS OF REMOVING AND ENTHRONEMENT OF THE BISHOPS OF ALEXANDRIA DURING THE ARIAN CONTROVERSY IN THE EAST}

\section{(Summary)}

Within the short period of time between the years 339 and 373, Alexandria witnessed to a frequent use of the armed forces with an eye to removing the current bishop or enthronement of another, who had been approved of by the imperial court. Local administration officials (for instance the praefectus Aegypti) and army officers (for example the dux Aegypti) were made use of in order to execute the current ruler's orders. The orders were sent by means of imperial officials, who, many a time, were to stay in Alexandria to see to execution of the imperial instructions. The developments of the year 356, when Athanasius was removed from the episcopal throne, show that the decision of using force against the hierarch was taken when all other efforts to remove the bishop from the Alexandrine cathedral proved to have been futile. The authorities were fully aware that there was a possibility of public unrest in the city, which, for example, because of the usurpations or other wars that were underway at that time, they wanted to avoid. In all the discussed instances, the imperial court was very careful about providing the new bishops with adequate military assistance, which was given by the troops coming from outside Alexandria itself. This measures prove that the emperors often considered the local military forces to be insufficient to execute the issued orders. The military was also used to arrest the bishop condemned to expulsion and they were active both in Alexandria as well as outside the city. It is also characteristic that the above mentioned measures would often prove to be ineffective. The newly appointed leaders of the local Church, supported by the troops, would often make use of the force to gain control over the local community. George of Cappadocia and Lucius were particularly active in this respect. They encouraged the military officers to act against not only Athanasius and Peters supporters, who came both from the clergy and laymen, but also against the monks belonging to the Pachomian monasteries, who, in turn, used to give firm support to the orthodox bishops. Such actions used to lead to frequent violence and unrest. The case of George of Cappadocia demonstrates the fact that his rule over the Church of Alexandria was possible only and uniquely thanks to the constant presence of the army. When the military assistance ceased to be effective, 
he was forced to flee for fear of loosing his life. In spite of the fact that the emperors managed to hand over the Alexandrine Church to the Arians, who were additionally supported by the military troops, the influence of the pro-Nicean group remained fairly influential. It was proved by Athanasius, and later Peter's, Athanasius' successor, repeated returns. Even emperor Valens, who was under a strong Arian influence, had to take into account the fact that, under special circumstances, and in order to ensure law and order in Alexandria, he would have felt forced to reconcile himself with an orthodox bishop in the city, even in spite of his former orders of the bishops forcible removing. 